\title{
PERBANDINGAN KEMAMPUAN KOMUNIKASI MATEMATIS BERDASARKAN TINGKAT KEMAPUAN SISWA MELALUI PENDEKATAN PROBLEM BASED LEARNING
}

\author{
Amiaji Salim \\ ${ }^{123}$ IKIP Siliwangi, JL. Terusan Jendral Sudirman, Cimahi, Jawa Barat, Indonesia \\ 12amiajisalim@ymail.com,2e2rht@yahoo.com³nhe.fitriani@gmail.com
}

\begin{abstract}
This study is aimed at analyzing students' mathematical communication skills based on the results of observations, namely the ability of junior high school students. Subjects consisted of 20 students with categories using high, medium, and low grades. The method used is the Problem Based Learning approach. Data obtained from student results because of student tests and how students in finding mathematical communication solutions students who can solve problems and can solve mathematical problems well. But few students can solve problems because students perceive that mathematics learning is very difficult, especially mathematics communication material. After the treatment of Problem Based Learning, children's results are better than classes that use normal learning. With the increase in the authors concluded that the Problem Based Learning approach can be further investigated with a lot of practice. researchers hope that the Problem Based Learning approach can add insight to students.
\end{abstract}

Keyword: Mathematical Communication, Problem Based Learning Approach

\begin{abstract}
Abstrak
Penelitian ini ditujukan untuk menganalisis kemampuan komunikasi matematika siswa berdasarkan hasil observasi yang peneliti uji yaitu kemampuan siswa SMP. Subjek terdiri dari 20 orang siswa dengan kategori menggunakan tingkatan nilai yang tinggi, sedang, dan rendah. Metode yang dipakai yaitu pendekatan Problem Based learning. Data diperoleh dari hasil siswa sebagai hasil tes siswa dan bagaimana siswa dalam mencari solusi komunikasi matematika siswa yang mampu menyelesaikan masalah dan dapat memecahkan masalah matematika dengan baik. Tetapi sedikit siswa yang dapat memecahkan masalah karena siswa menganggap bahwa pembelajaran matematika sangat sulit khususnya materi komunikasi matematika. Setelah adanya perlakuan Problem Based Learning, hasil anak lebih baik ketimbang kelas yang menggunakan pembelajaran biasanya. Dengan adanya peningkatan penulis menyimpulkan pendekatan Problem Based learning bisa di teliti lebih lanjut dengan banyak latihan. peneliti berharap dengan pendekatan Problem Based learning ini dapat menambah wawasan bagi siswa.
\end{abstract}

Kata Kunci: Komunikasi Matematis, Pendekatan Problem Based learning

How to cite: Salim, A., (2019). Perbandingan Komunikasi Matematika. Berdasarkan Tingkat Komunikasi Siswa melalui Pendekatan berbasis masalah. JPMI - Jurnal Pembelajaran Matematika Inovatif, 2 (5), 301-306. 


\section{PENDAHULUAN}

Berdasarkan fakta yang terjadi di lapangan ada beberapa masalah pada siswa yaitu siswa masih mengalami kesulitan untuk mencari ide atau menemukan solusinya. Ketika diberi soal cerita, siswa cenderung sulit memahami apa permasalahan dan apa yang di ditanyakan dalam soal tersebut sehingga dalam memahami soal cerita siswa cenderung rumit untuk menyelesaikannya. Siswa sering salah memahami maksud dari soal tersebut. Dengan itu juga siswa hanya mampu menyelesaikan soal yang sama setelah di contohkan guru dengan soal yang sudah diselesaikan oleh guru. Terdapat masalah di atas sehingga penulis menyimpulkan, dapat disimpulkan bahwa tingkat kemampuan komunikasi matematis siswa masih rendah. Saat menyelesaikan masalah berlangsung, maka terjadi solusi dari hasil diskusi bahwa pengetahuan antara siswa sudah menemukan solusinya, hal tersebut mempertajam pengetahuan siswa dalam mengembangkan kemampuan komunikasinya. Menurut Romberg dan Chair (Qohar, 2011), yaitu: menghubungkan benda tidak nyata dengan sebuah gambar, dan tabel ke dalam matematika secara lisan atau tulisan dengan benda nyata aljabar, grafik, gambar dan dll. dari kejadian selama siswa belajar sehari-hari ke dalam komunikasi atau bahasa matematika, siswa di arahkan untuk bisa berdiskusi, dan bisa menemukan solusi dalam memecahkan soal matematika, dapat mempresentasikan hasil di depan dengan bangga. Membuat siswa untuk menyimpulkan apa yang telah dipelajarinya. Mampu menulis soal atau membuat soal tentang pertanyaan matematika yang telah dipelajarinya.

Sejalan dengan itu menurut (Ansari, 2012) untuk mengetahui kemampuan komunikasi matematika siswa dalam pembelajaran matematika dapat dilakukan dengan pemberian soal uraian cerita yang bisa mengetahui kemampuan komunikasi matematika. Beberapa soal yang digunakan menggunakan tingkatan soal pemahaman, aplikasi, sintesis, dan evaluasi. Dengan itu menurut (Majid, $2013 \mathrm{hlm}$. 282) ada beberapa pengertian mengenai komunikasi. Pertama, pada intinya komunikasi adalah suatu penyampaian informasi kepada seseorang dalam menyampaikan maksud dan tujuan kepada si penerima pesan. Kemampuan kesuksesan komunikasi dapat dilihat dari apa yang ingin disampaikannya bisa berupa pesan atau informasi baik secara lisan maupun tulisannya. Kedua, komunikasi adalah alat penyampaian apa yang ingin disampaikan dari seseorang kepada orang lain. Hal yang paling penting dalam keberhasilan komunikasi adalah orang yang menyampaikan tujuan dan alasan pesan. Penerima hanya sebagai orang yang merima pesan dari orang lain. Ketiga, komunikasi diartikan sebagai penyampaian apa dan untuk siapa pesan itu disampaikan. Pemahaman ini ada 3, yaitu sebagai penyampai pesan, pesan dan penerima pesan haruslah setara. Proses ini menuntut bentuk pengiriman oleh pengirim, dan diterima oleh penerima, sehingga informasi dapat berguna bagi penerima informasi tersebut. Dengan pendapat di atas penulis menyimpulkan bahwa berkomunikasi adalah suatu hal yang terjadi dengan sendirinya, dari apa yang ingin disampaikan kepada lawan bicara dengan maksud menyampaikan ide atau gagasan kepada lawan bicara. Dengan berkomunikasi dapat memudahkan kita dalam berinteraksi. Dan berkomunikasi adalah suatu alat untuk berinteraksi dengan orang lain. Dalam matematika sendiri berkomunikasi sangat penting dalam memberikan materi untuk menunjang proses pembelajaran disekolah.

Dengan adanya pendekatan Problem Based Learning (PBL) siswa mempunyai solusi untuk mengatasi permasalahan di atas, siswa dapat memecahkan masalah dengan cara berkelompok, siswa cenderung aktif selain bisa memecahkan masalah, siswa pun mampu mengerjakan soal cerita dengan baik dengan diberikan penjelasan materi oleh guru. Guru menerangkan cara membuat soal yang baik dan bagaimana menjawab soal cerita matematika. (Amir, $2009 \mathrm{hlm}$. 21). Problem Based Learning (PBL) adalah pendekatan yang nyata pembelajaran yang 
mengharuskan siswa menghadapi masalah yang nyata dan sudah ada buktinya) untuk mengawali pembelajaran-pembelajaran ini adalah pembelajaran yang inovatif yang dapat memberikan kondisi belajar aktif dan kondusif kepada siswanya. Problem Based Learning (PBL) merupakan pengembangan pembelajaran dari zaman ke zaman. disusun masalah yang menuntut siswa mendapatkan pengetahuan yang sangat penting dan bermakna, membuat mereka pandai dalam memecahkan masalah, dan memiliki teknik belajar sendiri baik dalam tim ataupun sendiri. Proses pembelajarannya menggunakan pendekatan yang untuk memecahkan dan mencari solusi dari kehidupan yang telah dilalui sehari-sehari dan dapat mempelajarinya. Sejalan dengan itu (Amir, 2007). Pendekatan Problem Based Learning (PBL) penggunaan masalah kehidupan nyata sebagai suatu yang harus dipelajari siswa.

Dengan model PBL diharapkan siswa mendapatkan lebih banyak pengetahuan daripada pengetahuan yang diingat. Mulai dari pengetahuan memecahkan masalah, pengetahuan berpikir kritis, pengetahuan bekerja dalam kelompok, Menurut Mujianto, Zubaidi, et. al, hal ini sesuai dengan pendapat Dutch (Amir, $2009 \mathrm{hlm}$. 21) bahwa problem based learning merupakan yang mengharuskan siswa agar belajar bekerja sama dalam kelompok untuk mencari pemecahan permasalahan yang nyata atau solusi dalam kehidupan sehari-hari. Serta untuk mendapatkan hasil belajar yang maksimal (Nurhadi, 2004 hlm. 16). Selanjutnya, (Riyanto, $2010 \mathrm{hlm}$. 288) berpendapat problem based learning tidak jauh berbeda dengan pendapat sebelumnya siswa dianjurkan untuk bekerja kelompok secara tim. Kedua, langkah pemecahan masalah dalam PBL sejalan dengan karya ilmiah, yakni mengumpulkan data, dan bukti yang konkret dengan masalah yang sedang dialaminya, menemukan pendapat, menentukan pendapat, dan menerapkan pendapat yang dipilih untuk mencari solusi dalam memecahkan masalah yang dihadapi.

Langkah ini memotivasi mahasiswa untuk bersemangat dan aktif segera melakukan langkahlangkah pemecahan masalah. Pendapat tersebut sejalan dengan konsep (Barret, 2005) dan (Savery, 2006) tentang langkah-langkah pelaksanaan problem based learning yang mencakup; (a) siswa mempunyai masalah yang nyata, (b) siswa mengoreksi permasalahan yang diberikan; (c) menentukan definisi; (d) melakukan diskusi berdasarkan pengetahuan yang ditetapkan ; (e) menetapkan sebuah pemecahan menyelesaikan masalah yang di sulit dipecahkan.

Tabel 1. Tahapan-Tahapan Pendekatan Problem Based Learning (Rusmono, 2014 hlm. 81)

\begin{tabular}{ll}
\hline \multicolumn{1}{c}{ FASE-FASE } & \multicolumn{1}{c}{ PERILAKU GURU } \\
\hline $\begin{array}{l}\text { Tahap 1: } \\
\text { Mengarahkan siswa dalam memecahkan } \\
\text { masalah }\end{array}$ & $\begin{array}{l}\text { Guru memberitahukan tujuan } \\
\text { pembelajaran, menggambarkan kebutuhan } \\
\text { logika, dan memotivasi siswa agar bisa } \\
\text { memecahkan masalah dan mencari } \\
\text { solusinya sendiri dari apa yang diteliti dan } \\
\text { dipilihnya }\end{array}$ \\
$\begin{array}{l}\text { Guru membantu siswa untuk mengatur serta } \\
\text { Tahap 2: }\end{array}$ & $\begin{array}{l}\text { memberi arahan dalam memecahkan suatu } \\
\text { permasalahannya sendiri. }\end{array}$ \\
Mengarahkan siswa untuk belajar aktif & $\begin{array}{l}\text { Guru mengarahkan siswa mengumpulkan } \\
\text { informasi yang tepat dan akurat, } \\
\text { melaksanakan penelitian, mencari apa }\end{array}$ \\
Membantu penelitian secara mandiri dan & $\begin{array}{l}\text { permasalahannya, dan solusi. } \\
\text { kelompok }\end{array}$
\end{tabular}


Tahap 4:

mempresentasikan hasil karya serta hasil penelitian dengan bangga.

Tahap 5:

Menyimpulkan dan menilai dari proses memecahkan masalah
Guru membantu siswa untuk menyediakan hasil penelitian berupa laporan, rekaman, video, dan model, dan mampu mempresentasikan hasil penelitiannya Guru membantu siswa melakukan refleksi atas penelitian dan proses penelitian yang mereka lalui.

Berdasarkan pengertian menurut para ahli, maka dapat disimpulkan Problem Based Learning adalah pendekatan pembelajaran yang mengharuskan siswa untuk memecahkan permasalahan sendiri atau berkelompok sehingga siswa dapat berperan aktif dalam kelompok maupun mandiri, mengeluarkan ide-idenya, dapat menghargai pendapat teman sekelompoknya untuk menemukan solusi. Dan mampu menyelesaikan masalah yang sudah terjadi dan menyelesaikannya secara berkelompok.

\section{METODE}

Penelitian yang digunakan adalah metode kuantitatif yakni dalam pengumpulan data tersebut, siswa sebelumnya diberikan soal pretes terlebih dahulu. Setelah itu dilakukan pembelajaran menggunakan pendekatan biasa pada kelas kontrol dan pendekatan problem based learning pada kelas eksperimen selanjutnya pada masing-masing kelas diberikan soal postes. Populasi dalam penelitian ini adalah siswa MTS yang ada di Kabupaten Bandung Barat. Dengan sampelnya siswa MTS tersebut. Instrumen dalam penelitian ini adalah analisa kemampuan komunikasi matematika. Seluruh penelitian ini di ambil dengan menggunakan SPSS.

\section{HASIL DAN PEMBAHASAN}

\section{Hasil}

Pada hasil pretes, jumlah nilai kelas eksperimen total nilai 230. Sementara nilai kelas kontrol total nilai 215. Hasil postes jumlah nilai kelas eksperimen total nilai 250. Sementara nilai kelas kontrol total nilai 220. Dari hasil perolehan nilai siswa tersebut disimpulkan bahwa pendekatan problem based learning dapat meningkatkan kemampuan komunikasi.

Tabel 2. Nilai Siswa sebelum Menggunakan Pendekatan Problem based learning

PAM Experiments Control

\begin{tabular}{ccc}
\hline Tinggi & 85 & 80 \\
Sedang & 75 & 70 \\
Rendah & 70 & 65 \\
\hline Jumlah & 230 & 215
\end{tabular}


Tabel 3. Nilai Siswa setelah Menggunakan Pendekatan Problem based Learning

\begin{tabular}{ccc}
\hline PAM & Experiments & Control \\
\hline Tinggi & 90 & 80 \\
Sedang & 85 & 75 \\
Rendah & 75 & 65 \\
\hline Jumlah & 250 & 220 \\
\hline
\end{tabular}

Berdasarkan tabel 1 dan 2 di atas terdapat beberapa kesimpulan yang berkaitan dengan perolehan hasil belajar siswa, yaitu : pada hasil pretes, jumlah nilai kelas eksperimen nilai tertinggi 85 , Nilai sedang 85 , dan nilai terendah 70 total jumlah 230. Sementara nilai kelas kontrol nilai tertinggi 80, nilai sedang 70 dan nilai terendah 65 total nilai 215 .

Hasil postes jumlah nilai kelas eksperimen nilai tertinggi 90, Nilai sedang 85, dan nilai terendah 75 total nilai 250. Sementara nilai kelas kontrol nilai tertinggi 80, nilai sedang 75 dan nilai terendah 65 total nilai 220 .

\section{KESIMPULAN}

Dari pembahasan di atas penulis menyimpulkan bahwa pada pertemuan pertama jumlah perolehan nilai siswa pada kelas eksperimen dan Kontrol tidak terdapat perbedaan yakni berjumlah 230 dan 215. Sedangkan pada pertemuan kedua setelah menggunakan pendekatan problem based learning terdapat perbedaan jumlah perolehan nilai yakni pada kelas eksperimen 250 dan kelas kontrol 220. Dari hasil perolehan nilai siswa tersebut dapat disimpulkan bahwa pendekatan problem based learning dapat lebih sedikit meningkatkan komunikasi matematis.

\section{UCAPAN TERIMA KASIH}

Penulis mengucapkan terima kasih kepada Dr. Euis Eti Rohaeti selaku Warek 1 Sekaligus dosen pembimbing 1 dan Dr. Nelly Fitriani, M.Pd. selaku Ketua Prodi sekaligus dosen pembimbing 2. Juga kepada Kepala Sekolah MTS yang telah memberi izin untuk melaksanakan penelitian ini.

\section{DAFTAR PUSTAKA}

Amir. (2007). Inovasi Pendidikan Melalui Problem Based Learning. Surakarta: UNS Press.

Amir. (2009). Dasar- Dasar Penulisan Karya Ilmiah. Jakarta: Kencana Prenada Media Grup.

Ansari, B. I. (2012). Komunikasi Matematik dan Politik. Surakarta: UNS Press.

Barret, T. (2005). Understanding Problem Based Learning. Handbook of Enquiry and

Problem-based Learning: Irish Case Studies and International Perspectives. Maynooth:

AISHE READINGS. 
Majid, A. (2013). Strategi Pembelajaran. Bandung: Remaja Rosdakarya.

Nurhadi. (2004). Pembelajaran Kontekstual dan Penerapannya dalam KBK. Malang: UM Press.

Qohar, A. (2011). Pengembangan Instrumen Komunikasi Matematis Untuk Siswa SMP. Lomba Dan Seminar Matematika XIX, XIX.

Riyanto, Y. (2010). Metodologi Penelitian Pendidikan. Surabaya: Penerbit SIC.

Rusmono. (2014). Strategi Pembelajaran dengan Problem Based Learning Itu Perlu. Jakarta: Ghalia Indonesia.

Savery, J. R. (2006). Overview of Problem - based Learning: Definitionsand Distinctions. Interdisciplinary Journal, 1(1), 9. 